\title{
Study of Bandgap Energy of Novel $\left(\mathrm{Cu}_{0.5} \mathrm{Ba}_{0.5} \mathrm{Fe}_{12} \mathrm{O}_{19}\right)_{1-\mathrm{x}} /\left(\mathrm{Co}_{0.6} \mathrm{Zn}_{0.4} \mathrm{Fe}_{2} \mathrm{O}_{4}\right)_{\mathrm{x}}$ Nanocomposite
}

\author{
Allwin Sudhakaran, Ashwin Sudhakaran, E. Siva Senthil
}

\begin{abstract}
In this novel work, we have studied the optical properties of $\mathrm{CuBaM-CZFO}$ nanocomposites. $\left(\mathrm{Cu}_{0.5} \mathrm{Ba}_{0.5} \mathrm{Fe}_{12} \mathrm{O}_{19}\right)_{1-x} /\left(\mathrm{Co}_{0.6} \mathrm{Zn}_{0.4} \mathrm{Fe}_{2} \mathrm{O}_{4}\right) \quad x$ [where $\left.x=0.1,0.2\right]$ nanocomposites were synthesized individually by sol-gel citrate method and then made into nanocomposites by physical mixing technique. Further characterization over their structural, morphological and optical properties were carried out in detail. With the help of UV analysis, the optical properties such as, the band gap energy was discovered which is found using Tauc's plot. The bandgap energy is $2.6503 \mathrm{eV}$ for CUBaM-CZFO 90-10 which is lesser than CuBaM-CZFO 80-20 (2.8456eV). The structural, morphological and optical properties of novel CUBaM-CZFO nanocomposite are reported and compared with, both among themselves and from the literature review.
\end{abstract}

Key Words: Doped Barium Hexaferrite, Cobalt Zinc Ferrite, Sol-gel Citrate, Physical Mixing, Bandgap Energy.

\section{INTRODUCTION}

The study on nanocomposites have extensively gained interest among the scientists due to its applications in numerous field [1]. In order to make a nanocomposite, two different materials with dissimilar geometric arrangements (0-3/2-2/1-3 types) are joined together using appropriate preparation techniques[2]. Among them the 0-3 type nanocomposites have a greater advantage due to its simple preparation techniques and less reaction between the different phases within the composite [3]. Recently many scientists have successfully enhanced the electrical, magnetic and dielectric properties of these nanocomposites. [4]- [7]. But the study of optical properties of such new nanocomposite is not done elsewhere as per the authors view. In case of nanocomposites, ferrite magnetic materials could be found in common. The main goal of this research is to create a new nanocomposite $\mathrm{Cu}$ doped barium hexaferrite/ Cobalt zinc ferrite. Choosing the hard and soft site material for the preparation of nanocomposite is the most vital part since the ferrite properties varies entirely based on the preparation and properties of these materials. For the hard site material Copper doped barium hexaferrite is chosen.

Manuscript received on November 13, 2021.

Revised Manuscript received on November 18, 2021.

Manuscript published on November 30, 2021.

* Correspondence Author

Allwin Sudhakaran*, Department of Physics, Karpagam Academy of Higher Education, Coimbatore (Tamil Nadu), India

Ashwin Sudhakaran, Department of Physics, Karpagam Academy of Higher Education, Coimbatore (Tamil Nadu), India

E. Siva Senthil, Department of Physics, Karpagam Academy of Higher Education, Coimbatore (Tamil Nadu), India. E-mail. Id. sivasenthil.e@kahedu.edu.in

(C) The Authors. Published by Blue Eyes Intelligence Engineering and Sciences Publication (BEIESP). This is an open access article under the CC BY-NC-ND license (http://creativecommons.org/licenses/by-nc-nd/4.0/)
Cobalt zinc ferrite is chosen as the soft site material. Both the phases were prepared by sol-gel citrate method, which has many advantages over the other conventional methods such as low reaction time and cost effective. These hard and soft sites are made into composites with different weight ratio such as $90 \%$ hard site with $10 \%$ soft site and $80 \%$ hard site with $20 \%$ soft site respectively $\left[\left(\mathrm{Cu}_{0.5} \mathrm{Ba}_{0.5} \mathrm{Fe}_{12} \mathrm{O}_{19}\right)_{1-\mathrm{x}} /\left(\mathrm{Co}_{0.6} \mathrm{Zn}_{0.4} \mathrm{Fe}_{2} \mathrm{O}_{4}\right)_{\mathrm{x}}\right]$ with the help of physical mixing method. The prepared nanocomposites are sintered at $800^{\circ} \mathrm{C}$ for 3 hours before sending them for further characterization studies. The outline of the research carried out by the author is shown below in figure 1 .

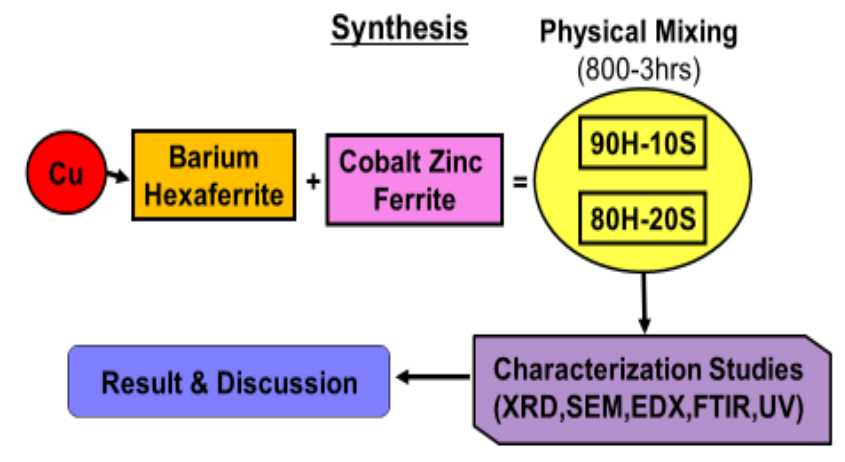

Figure 1. Outline of the article.

\section{LITERATURE REVIEW}

S. Vadivelan et.al (2016) synthesized copper doped barium hexaferrite using coprecipitation method at various weight percentages to enhance the coercivity value which increased the storage capacity in the prepared sample. From the VSM analysis, the copper doping percentage $(0-8 \%)$ is found to increase with the coercivity value (851.128 -856.651 Oe). After adding $\mathrm{Cu}$, the magnetic saturation increased from $11.7 \mathrm{emu} / \mathrm{g}$ to $34.9 \mathrm{emu} / \mathrm{g}$ [8]. Sunil Kumar et.al (2019), studied the relation between the structure of $\mathrm{Cu}$ doped $\mathrm{BaFe}_{12} \mathrm{O}_{19}$ with Magnetic and Dielectric Parameters prepared by citrate sol-gel method. He found out that the copper ions do not enter into the iron lattice of barium hexaferrite for $x \geq 1.0$ [9]. Ravindra C. Alange et.al (2021), synthesized $\mathrm{Co}_{1-\mathrm{x}} \mathrm{Zn}_{\mathrm{x}} \mathrm{Fe}_{2} \mathrm{O}_{4} \quad(\mathrm{x}=0.0,0.2 \quad \& \quad 0.4)$ autocombustion technique. He found that the Ms increases with $\mathrm{Zn}$ content while $\mathrm{M}_{\mathrm{r}}$ and $\mathrm{H}_{\mathrm{C}}$ decreases. It may be due to the fact that nonmagnetic zinc replaces magnetic $\mathrm{Co} 2+$ ions [10]. Mangalam M.K et.al (2020) prepared barium hexaferrite copper zinc ferrite nanocomposite using high energy ball milling technique.

\section{Published By:}

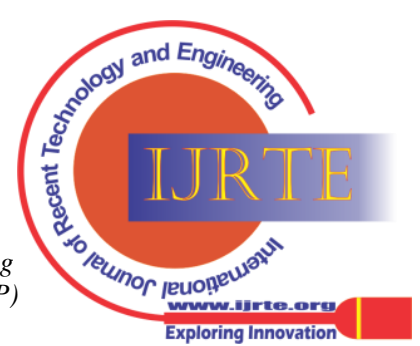


He investigated the interaction of magnetic phases which came to a conclusion that the prepared nanocomposite showed maximum Ms \& $\mathrm{Hc}$ at $77 \mathrm{emu} / \mathrm{g}$ and $3.8 \mathrm{kOe}$ at $60 \mathrm{~K}$ respectively. His further studies in another article (2021) stated that the Ms Value increases with the $\mathrm{CoZnFe}_{2} \mathrm{O}_{4}$ concentration. [11]-[13].

\section{METHODOLOGY}

\section{A. Preparation of Hard site material}

Nanocrystalline copper doped barium hexaferrite were synthesized by sol-gel citrate technique. The nitrates of Barium, Iron, Copper and citric acid were put into the deionized water. The ratio of citric acid to nitrates is 1:2. The $\mathrm{pH}$ of the mixture is kept at 7 by using ammonia. The resultant powder was grounded with mortar and pestle and it is annealed at $850{ }^{\circ} \mathrm{C}$ for 2 hours [14].

\section{Synthesis of Cu-BaM}

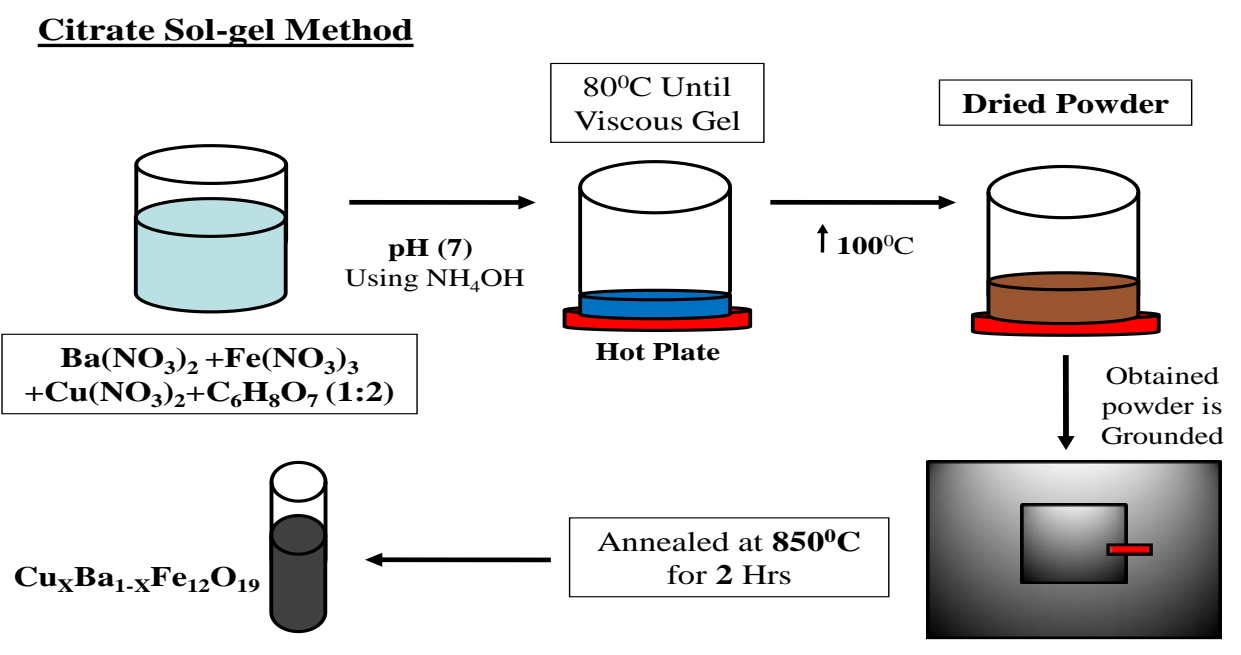

Figure 2. Synthesis of Copper doped Barium hexaferrite (CuBaM) by Sol-gel Citrate Method.

\section{B. Preparation of Soft site material}

Cobalt Zinc ferrite nanoparticles were prepared by auto-combustion synthesis. Where Under fierce stirring, the nitrates of Zinc, Cobalt and ferric are mixed in stoichiometric amounts. The citric acid ratio to the nitrates of metal is 1:1. The mixture was maintained at constant stirring and temperature is gradually increased until a viscous gel form. Later the solution is kept under fierce stirring and the temperature is increased to $75^{\circ} \mathrm{C}$ until the solution turns to dry powder. Finally, the dried powders were ground and annealed at 800 Celsius for 5 hours to get the desired Cobalt Zinc ferrite nanoparticles [15].

\section{Synthesis of CZFO}

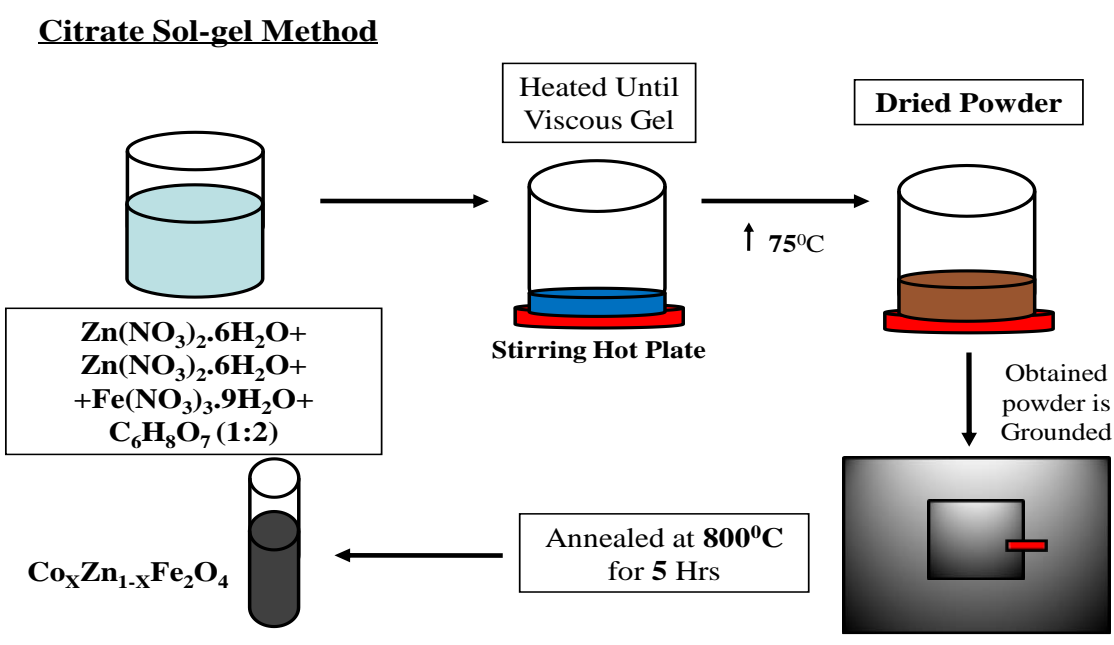

Figure 3. Synthesis of $\mathrm{CoZnFe}_{2} \mathrm{O}_{4}$ by Citrate Sol-Gel Method.

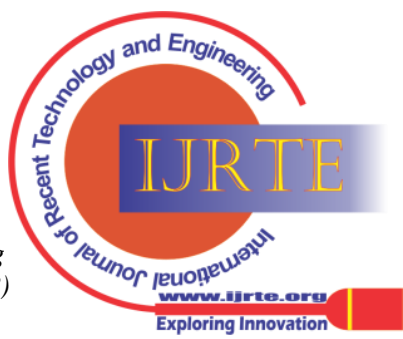




\section{Preparation of Nanocomposite material}

For the preparation of nanocomposite, physical mixing method is used[16], [17]. In this method, Copper doped $\mathrm{BaFe}_{12} \mathrm{O}_{19}$ was physically stirred with $\mathrm{CoZnFe}_{2} \mathrm{O}_{4}$ at various hard to soft site such as $90 / 10$ and $80 / 20$ to make the nanocomposites $\left[\left(\mathrm{Cu}_{0.5} \mathrm{Ba}_{0.5} \mathrm{Fe}_{12} \mathrm{O}_{19}\right)_{1-\mathrm{x}} /\left(\mathrm{Co}_{0.6} \mathrm{Zn}_{0.4} \mathrm{Fe}_{2} \mathrm{O}_{4}\right)_{\mathrm{x}}\right]$. These are denoted CuBaM-CZFO 90/10, CuBaM-CZFO $80 / 20$ respectively. The resultant mixture is mixed and grounded for 60 minutes and were annealed at $800^{\circ} \mathrm{C}$ for $3 \mathrm{~h}$ in air atmosphere and are given for characterization.

\section{EXPERIMENTAL TECHNIQUES}

The following characterization is done over the prepared nanocomposites. The Structural analysis is done using XRD (3rd generation Empyrean, Malvern Panalytical) with $\mathrm{Cu} \mathrm{K \alpha}$ $(\lambda=1.540598 \AA)$ radiation. FTIR (Shimadzhu, IR affinity 1A) were recorded within 4000-400 cm-1 range to conform Spinel and M-type hexaferrite metal-oxygen bond formation. Particle size distribution and morphology studies were done using SEM Jeol JSM 6390model armed with EDX for elemental studies. The optical parameters of nanocomposite were studied within 200-800nm range using UV-2400PC Series with slit width $1.0 \mathrm{~nm}$ and light source of wavelength $360 \mathrm{~nm}$. From the UV analysis the bandgap energy was calculated using tauc's plot.

\section{A. XRD Analysis}

The structural analyses of all the prepared samples are carried out using XRD. All peak points are indexed with respect to JCPDS card no 78-0133 and 88-2152 for CuBaM and CZFO respectively. It confirms the hexagonal CuBaM structure with P63/mmc space group; and cubic CZFO structure with Fd-3m space group respectively. The cell volume \& lattice values for all prepared nanocomposites are calculated and it matches with the standard JCPDS card data.
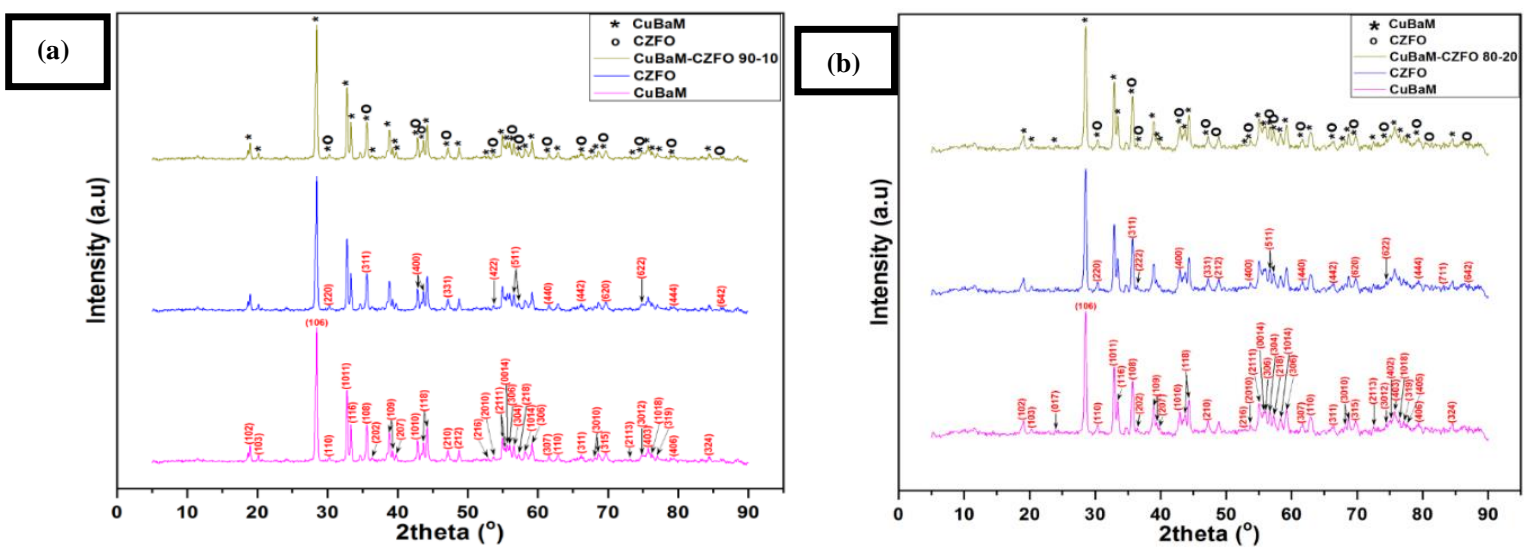

Figure 4.XRD patterns for (a) CuBaM-CZFO 90-10 and (b) CuBaM-CZFO 80-20 respectively.

Table 1. Lattice parameter and cell volume for CuBaM CZFO 80-20 and CuBaM CZFO 90-10.

\begin{tabular}{|c|c|c|c|}
\hline CuBaM : JCPDS: 78-0133 CZFO :JCPDS: 88-2152 & $\mathbf{a}$ & c & Cell Volume(V) \\
\hline Standard Value (CuBaM) & 5.865 & 23.099 & 688.1131 \\
\hline Standard Value (CZFO) & 8.396 & $=$ & 591.8577 \\
\hline \multicolumn{4}{|c|}{ Calculated Value CuBaM CZFO 80-20 } \\
\hline CuBaM(0014) & - & 23.03141 & \multirow{2}{*}{683.9746} \\
\hline CuBaM (210) & 5.85591 & - & \\
\hline CZFO (311) & 8.303172 & $=$ & 572.4428 \\
\hline \multicolumn{4}{|c|}{ Calculated Value CuBaM CZFO 90-10 } \\
\hline CuBaM(0014) & - & 23.0656 & \multirow{2}{*}{688.2714} \\
\hline CuBaM(210) & 5.86992 & - & \\
\hline CZFO (311) & 8.327897 & $=$ & 577.5719 \\
\hline
\end{tabular}

The average crystalline size of the prepared nanocomposites is measured using Scherrer's equation as shown in the table 2. Where to calculate the average size for CuBaM-CZFO the peaks (106), (1011), (116), (108), (109), (118) is used by substituting $\mathrm{K}=0.89$. Here we can clearly see that for CuBaM-CZFO the average crystalline size increases with increase in hard site concentration.

Table 2. Average crystalline size of CuBaM-CZFO nanocomposite calculated using Scherrer's equation.

\begin{tabular}{|c|c|c|c|c|c|c|}
\hline \multirow{2}{*}{ Sample } & \multirow{2}{*}{ H-S } & \multirow{2}{*}{ Peaks Taken } & \multicolumn{2}{|c|}{ Range of particles (nm) } & \multirow{2}{*}{$\begin{array}{c}\text { Average size } \\
\text { (nm) }\end{array}$} & \multirow{2}{*}{ Inference } \\
\hline & & & From & To & & \\
\hline \multirow{2}{*}{$\begin{array}{l}\text { CuBaM } \\
\text { CZFO }\end{array}$} & $80-20$ & \multirow{2}{*}{$\begin{array}{c}\text { (106),(1011),(116), } \\
(108),(109),(118)\end{array}$} & 20.60 & 28.02 & 24.65 & \multirow{2}{*}{$\begin{array}{l}\text { Increases with increase } \\
\text { in hard site }\end{array}$} \\
\hline & $90-10$ & & 24.94 & 37.14 & 31.81 & \\
\hline
\end{tabular}

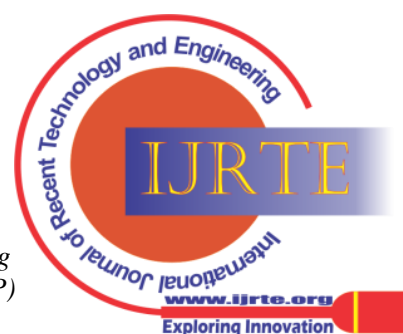




\section{B. Morphological Analysis}

The SEM along with histogram of particle size of CuBaM-CZFO samples are shown in figures 5 . The surface of the prepared samples is found to have a good crystalline formation were few particles joined together due to agglomeration within the individual particle in the sample. Spherical microstructure has been detected from the SEM Image. All the prepared samples have similar distribution which is interesting to have a uniform distribution of particles (as shown in figure 5). The SEM size differs from the Size obtained from XRD. This may be due to agglomeration [18]. It is the characteristic nature of the ferrite materials.
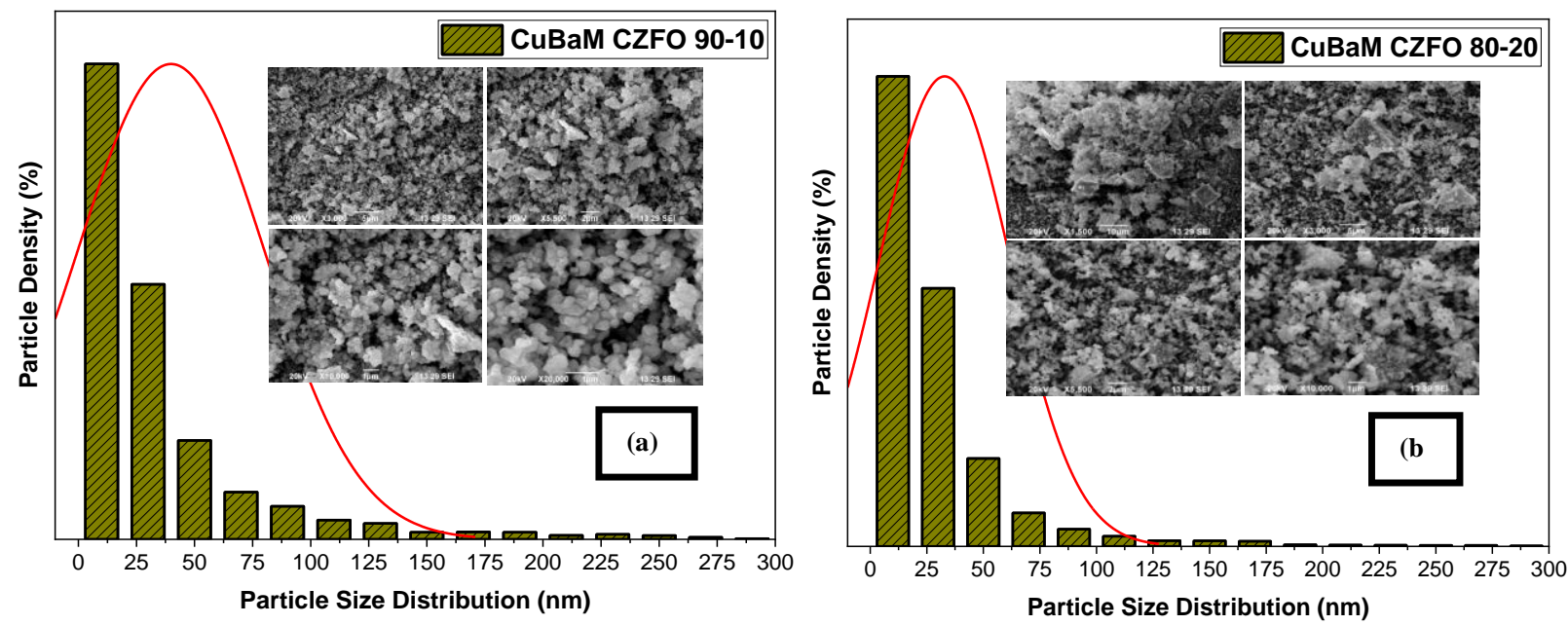

Figure 5. Typical SEM with histogram of particle size distribution in CuBaM-CZFO (a) 90-10 and (b) 80-20 nanocomposite.

The EDAX study was made on all prepared samples. figure 6 shows the existence of Copper, Barium, Cobalt, Zinc, Fe and Oxygen elements in CuBaM CZFO 90-10 and 80-20 samples respectively. The data obtained from EDX are tabulated in table 3.
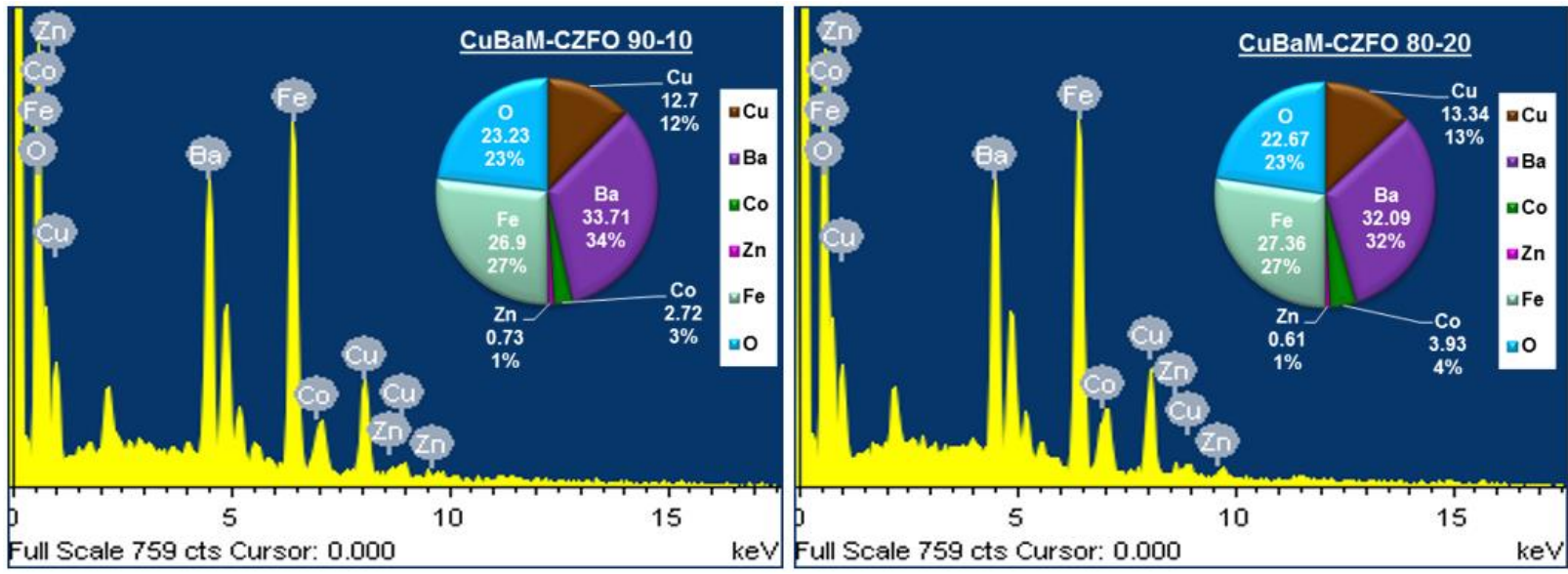

Figure 6. EDAX analysis for CuBaM-CZFO revealing Cu, Ba, Co, Zn, Fe \& $\mathrm{O}$ with weight \%.

Table 3. Typical weight percentage of different elements in CuBaM CZFO 90-10 and 80-20 samples.

\begin{tabular}{|c|c|c|c|c|c|c|c|}
\hline \multirow[b]{2}{*}{ Sample } & \multirow[b]{2}{*}{ Element } & \multicolumn{3}{|c|}{$90-10$} & \multicolumn{3}{|c|}{$80-20$} \\
\hline & & $\begin{array}{c}\text { Apparent } \\
\text { Concentration }\end{array}$ & Weight \% & Atomic \% & $\begin{array}{c}\text { Apparent } \\
\text { Concentration }\end{array}$ & Weight \% & Atomic \% \\
\hline \multirow{6}{*}{$\begin{array}{c}\text { CuBaM- } \\
\text { CZFO }\end{array}$} & $\mathrm{Cu}$ & 4.48 & 12.70 & 8.20 & 4.70 & 13.34 & 8.65 \\
\hline & $\mathrm{Ba}$ & 12.41 & 33.71 & 10.07 & 11.83 & 32.09 & 9.63 \\
\hline & Co & 1.00 & 2.72 & 1.90 & 1.45 & 3.93 & 2.75 \\
\hline & $\mathrm{Zn}$ & 0.26 & 0.73 & 0.46 & 0.22 & 0.61 & 0.38 \\
\hline & $\mathrm{Fe}$ & 9.84 & 26.90 & 19.77 & 10.04 & 27.36 & 20.19 \\
\hline & $\mathrm{O}$ & 13.94 & 23.23 & 59.60 & 13.53 & 22.67 & 58.39 \\
\hline Total & & \multicolumn{3}{|c|}{100.00} & \multicolumn{3}{|c|}{100.00} \\
\hline
\end{tabular}

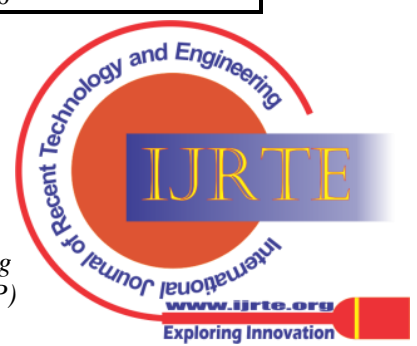




\section{FTIR Analysis:}

The FTIR analysis of CuBaM-CZFO nanocomposites shows the presence of v1, v2 and v3 bands as shown in the figure 7. The band v1 was found in 538-605 $\mathrm{cm}^{-1}$ range due to $\mathrm{Zn}^{2+}$ tetrahedral stretching complexes. Band V2 in $410-470 \mathrm{~cm}^{-1}$ range, represents octahedral complexes, which corresponds to the presence of $\mathrm{Fe}-\mathrm{O}$ stretching vibrations. These confirms the presence of $\mathrm{M}-\mathrm{O}$ stretching in ferrites metaloxygen bonds. These are attributed to the formation of hexaferrite structure including octahedral and tetrahedral sites.

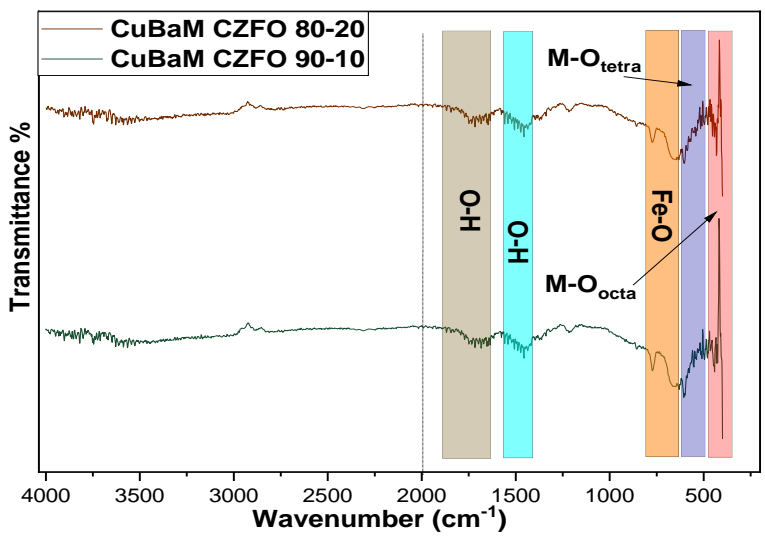

Figure 7. FTIR Graph of CuBaM-CZFO 90-10 and CuBaM-CZFO 80-20
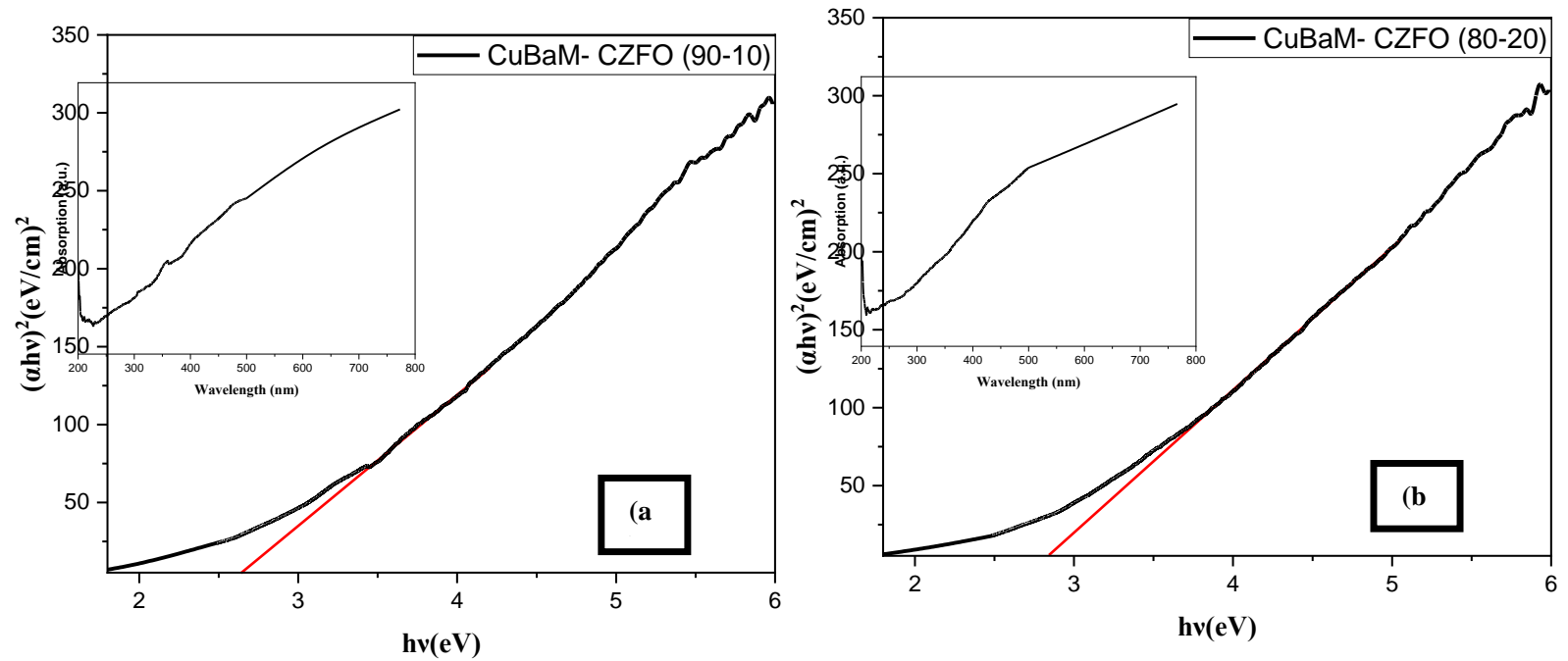

Figure 8. Absorption vs wavelength with Tauc's plot for (a) CuBaM-CZFO 90-10 and (b) CuBaM-CZFO 80-20 respectively.

\section{CONCLUSION}

A novel nanocomposite of $\mathrm{Cu}$ doped barium hexaferrite/ Cobalt zinc ferrite is successfully synthesized using physical mixing method. Generally, the optical parameters in nanocomposites are greatly affected via synthesis, temperature, and the concentration of the hard and soft sites. The XRD Analysis revealed successful hexagonal and spinel formation in the prepared nanocomposite material. The cell volume, and the lattice a and c are calculated which matched with JCPDS card data.

The cell volume, lattice a and c increase with increase in the hard site concentration. Similarly, the average crystalline size calculated by Scherrer's equation also showed increase in size of the crystal with CuBaM concentration. The SEM and histogram of particle distribution are investigated showing good crystalline nature with spherical
Table 4. FTIR Table for the prepared nanocomposite.

\begin{tabular}{|c|c|}
\hline $\begin{array}{l}\text { Absorption } \\
\left(\mathrm{cm}^{-1}\right)\end{array}$ & Functional Group \\
\hline V2 (410-470) & Fe-O Stretching confirming $\mathrm{M}-\mathrm{O}_{\text {octa }}$ \\
\hline V1 (538-605) & $\mathrm{M}-\mathrm{O}_{\text {tetra }}$ \\
\hline 551,569 & Characteristic peak of $\mathrm{CoFe}_{2} \mathrm{O}_{4}$ \\
\hline V3 (630-773) & Characteristic peak of Fe-O \\
\hline $1138-1496$ & O-H bending \\
\hline 1635 & $\begin{array}{l}\text { O-H bending, Evidence for M-Ferrite } \\
\text { nanoparticles formation }\end{array}$ \\
\hline
\end{tabular}

\section{Optical Analysis}

The optical Analysis of the samples prepared were investigated within 200-800nm range using UV-2400PC Series with slit width $1.0 \mathrm{~nm}$ and light source of wavelength $360 \mathrm{~nm}$. From the UV analysis the bandgap energy was calculated using tauc's plot as shown in figure8. It is found that the bandgap for CuBaM-CZFO 90-10 (2.6503eV) is lesser than CuBaM-CZFO 80-20 (2.8456eV). Thus, the bandgap energy Increases with the decrease in the hardsite concentration.
Published By:

Blue Eyes Intelligence Engineering and Sciences Publication (BEIESP) (C) Copyright: All rights reserved. microstructure. It is interesting to find a uniform grain size distribution in the prepared sample. The quantitative data extracted from the EDAX spectrum confirms the purity of the prepared nanocomposite material.

The presence of band $\mathrm{v}_{1}, \mathrm{v}_{2}$ and $\mathrm{v}_{3}$ in FTIR analysis confirmed the formation of both Metal-Oxide bonds of tetrahedral and octahedral sites as well as the formation of hexagonal structure in the prepared sample.

The study of band gap energy from Tau's plot using UV analysis revealed maximum band gap of $2.8456 \mathrm{eV}$ for CuBaM-CZFO 80-20 nanocomposite which increases with the soft site concentration. These novel results are amazing and unique according to the Author point of view.

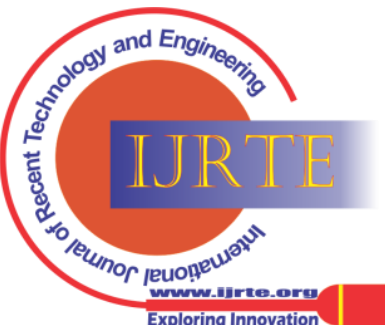




\section{Study of Bandgap Energy of Novel $\left(\mathrm{Cu}_{0.5} \mathrm{Ba}_{0.5} \mathrm{Fe}_{12} \mathrm{O}_{19}\right)_{1-\mathrm{x}} /\left(\mathrm{Co}_{0.6} \mathrm{Zn}_{0.4} \mathrm{Fe}_{2} \mathrm{O}_{4}\right)_{x}$ Nanocomposite}

\section{DECLARATION OF COMPETING INTEREST}

The authors declare that they have no known competing financial interests or personal relationships that could have appeared to influence the work reported in this paper.

\section{ACKNOWLEDGEMENT}

We, the authors are grateful to our President, Chancellor, Chief Executive Officer, Vice Chancellor and Registrar of Karpagam Academy of Higher Education, Coimbatore, India for providing facilities and encouragement. Our thanks are also due to Sophisticated Analytical Instrument Facility (SAIF) for VSM Analysis.

\section{REFERENCES}

1. S. D. Bader, "Colloquium: Opportunities in nanomagnetism," Reviews of Modern Physics, vol. 78, no. 1, 2006, doi: 10.1103/RevModPhys.78.1.

2. Y. Wang, J. Hu, Y. Lin, and C. W. Nan, "Multiferroic magnetoelectric composite nanostructures," NPG Asia Materials, vol. 2, no. 2. pp. 61-68, Apr. 2010. doi: 10.1038/asiamat.2010.32.

3. R. Kumar, S. Guha, R. K. Singh, and M. Kar, "Surface anisotropy induced magnetism in $\mathrm{BaTiO}-\mathrm{CoFe} 2 \mathrm{O} 4$ (BTO-CFO) nanocomposite," Journal of Magnetism and Magnetic Materials, vol. 465, pp. 93-99, Nov. 2018, doi: 10.1016/j.jmmm.2018.05.061.

4. D. T. M. Hue et al., "Synthesis, structure, and magnetic properties of SrFe12O 19/La1-xCaxMnO3 hard/soft phase composites," Journal of Applied Physics, vol. 114, no. 12, Sep. 2013, doi: 10.1063/1.4821971.

5. N. A. Algarou et al., "Magnetic and microwave properties of $\mathrm{SrFe} 12 \mathrm{O} 19 / \mathrm{MCe} 0.04 \mathrm{Fe} 1.96 \mathrm{O} 4(\mathrm{M}=\mathrm{Cu}, \mathrm{Ni}, \mathrm{Mn}$, Co and $\mathrm{Zn})$ hard/soft nanocomposites," Journal of Materials Research and Technology, vol. 9, no. 3, pp. 5858-5870, 2020, doi: 10.1016/j.jmrt.2020.03.113.

6. A. Quesada, F. Rubio-Marcos, J. F. Marco, F. J. Mompean, M García-Hernández, and J. F. Fernández, "On the origin of remanence enhancement in exchange-uncoupled CoFe2O4-based composites," Applied Physics Letters, vol. 105, no. 20, Nov. 2014, doi: 10.1063/1.4902351.

7. [7] K. Raidongia, A. Nag, A. Sundaresan, and C. N. R. Rao, "Multiferroic and magnetoelectric properties of core-shell CoFe2 O4 @ BaTiO3 nanocomposites," Applied Physics Letters, vol. 97, no. 6, Aug. 2010, doi: 10.1063/1.3478231.

8. S. Vadivelan and N. Victor Jaya, "Investigation of magnetic and structural properties of copper substituted barium ferrite powder particles via co-precipitation method," Results in Physics, vol. 6, pp. 843-850, 2016, doi: 10.1016/j.rinp.2016.07.013.

9. S. Kumar, S. Guha, S. Supriya, L. K. Pradhan, and M. Kar, "Correlation between crystal structure parameters with magnetic and dielectric parameters of Cu-doped barium hexaferrite," Journal of Magnetism and Magnetic Materials, vol. 499, Apr. 2020, doi: 10.1016/j.jmmm.2019.166213.

10. R. C. Alange and R. C. Alange, "Structural and Magnetic Properties of Zn2+ Doped Cobalt Ferrite Nanoparticles Synthesized by Sol-gel Auto Combustion Method Structural and Magnetic Properties of Zn 2+ Doped Cobalt Ferrite Nanoparticles Synthesized by Sol-gel Auto Combustion Method," Article in International Journal of Science and Research, 2021, doi: 10.21275/SR21719065226.

11. M. K. Manglam, J. Mallick, S. Kumari, R. Pandey, and M. Kar, "Crystal structure and magnetic properties study on barium hexaferrite (BHF) and cobalt zinc ferrite (CZF) in composites," Solid State Sciences, vol. 113, Mar. 2021, doi: 10.1016/j.solidstatesciences.2020.106529.

12. M. K. Manglam, S. Kumari, S. Guha, S. Datta, and M. Kar, "Study of magnetic interaction between hard and soft magnetic ferrite in the nanocomposite," in 3RD INTERNATIONAL CONFERENCE ON CONDENSED MATTER AND APPLIED PHYSICS (ICC-2019), May 2020, vol. 2220, p. 110020. doi: 10.1063/5.0001220.

13. J. Mallick, M. K. Manglam, S. Datta, and M. Kar, "Evidence of magnetic interaction between $\mathrm{BaFe} 12 \mathrm{O} 19$ and $\mathrm{CuFe} 2 \mathrm{O} 4$ in the nanocomposite," in 3RD INTERNATIONAL CONFERENCE ON CONDENSED MATTER AND APPLIED PHYSICS (ICC-2019), May 2020, vol. 2220, p. 110025. doi: 10.1063/5.0001223.

14. S. Kumar, S. Guha, S. Supriya, L. K. Pradhan, and M. Kar, "Correlation between crystal structure parameters with magnetic and dielectric parameters of Cu-doped barium hexaferrite," Journal of
Magnetism and Magnetic Materials, vol. 499, p. 166213, 2020, doi: 10.1016/j.jmmm.2019.166213.

15. J. Feng, R. Xiong, Y. Liu, F. Su, and X. Zhang, "Preparation of cobalt substituted zinc ferrite nanopowders via auto-combustion route: an investigation to their structural and magnetic properties," Journal of Materials Science: Materials in Electronics, vol. 29, no. 21, pp. 18358-18371, 2018, doi: 10.1007/s10854-018-9950-y.

16. J. D. Bobić et al., "PZT-nickel ferrite and PZT-cobalt ferrite comparative study: Structural, dielectric, ferroelectric and magnetic properties of composite ceramics," Ceramics International, vol. 44, no. 6, pp. 6551-6557, Apr. 2018, doi: 10.1016/j.ceramint.2018.01.057.

17. A. Alipour, S. Torkian, A. Ghasemi, M. Tavoosi, and G. R. Gordani, "Magnetic properties improvement through exchange-coupling in hard/soft SrFe12O19/Co nanocomposite," Ceramics International, vol. 47, no. 2, pp. 2463-2470, Jan. 2021, doi: 10.1016/j.ceramint.2020.09.089.

18. S. Kumar, S. Supriya, L. K. Pradhan, and M. Kar, "Effect of microstructure on electrical properties of $\mathrm{Li}$ and $\mathrm{Cr}$ substituted nickel oxide," Journal of Materials Science: Materials in Electronics, vol. 28, no. 22, pp. 16679-16688, Nov. 2017, doi: 10.1007/s10854-0177580-4.

\section{AUTHORS PROFILE}

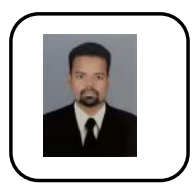

Allwin Sudhakaran, Research Scholar Department of Physics, Karpagam Academy of Higher Education, Coimbatore-641021, Tamilnadu, India. Phone: +91 9500439546. Email ID: dr.allwinsudhakar@gmail.com. ORCID ID: https://orcid.org/0000-0001-6361-7364

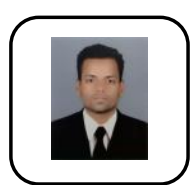

Ashwin Sudhakaran, Research Scholar Department of Physics, Karpagam Academy of Higher Education, Coimbatore-641021, Tamilnadu, India. Phone: +91 9003995469. Email ID: dr.ashwinsudhakar@gmail.com. ORCID ID: https://orcid.org/0000-0001-7408-5711

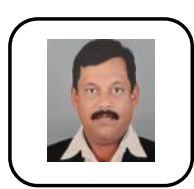

Dr. E. Sivasenthil, Associate Professor, Department of Physics, Karpagam Academy of Higher Education, Coimbatore-641021, Tamilnadu, India. Phone: +91 9842950616. Email ID: sivasenthil.e@kahedu.edu.in. ORCID ID: : https://orcid.org/0000-0002-2302-4748
Published By:

Blue Eyes Intelligence Engineering and Sciences Publication (BEIESP) (C) Copyright: All rights reserved.

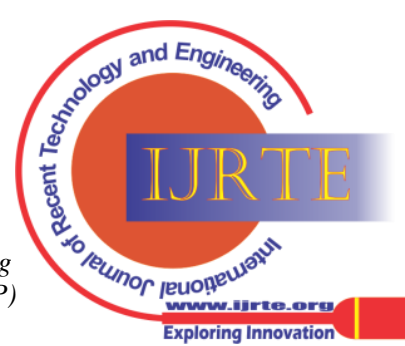

